\title{
EKSTERNALITAS TEMPAT PENGOLAHAN SAMPAH TERPADU (TPST) PIYUNGAN KABUPATEN BANTUL DAERAH ISTIMEWA YOGYAKARTA
}

\author{
Tri Widyaningsih, Ahmad Ma'ruf \\ Fakultas Ekonomi dan Bisnis Universitas Muhammadiyah Yogyakarta \\ Jalan Lingkar Selatan, Tamantirto, Kasihan, Bantul, Yogyakarta 55183 \\ Email Korespondensi: triwidya30@gmail.com
}

Naskah Diterima: Januari 2017; Disetujui: April 2017

\begin{abstract}
This research is to analyze both the positive and negative externalities of TPST Piyungan. The objects of this research are the people who lived around TPST Piyungan within the distance of less then $1 \mathrm{~km}$ from TPST Piyungan. The primary data are used from questionnaires, observation and interviews with 120 respondents using census method. The analysis in this research is descriptive statistics, income analysis, cost of illness, replacement cost and value added. The results indicate that the existence of TPST Piyungan influenced toward the economical and social aspects as well as the environment of the people around it. The positive externalities value estimation is Rp109.847.940,00/year and the negative externalities value for the people are Rp71.343.000,00/year. Inorganik waste utilization of TPST Piyungan, can give value added Rp632,00/kg for scavengers and Rp392,00/kg for collectors.
\end{abstract}

Keywords: externalities, cost of illness, replacement cost, value added, Integrated Waste Management Facility (TPST)

JEL Classification: H23, I15, F64

Abstrak: Penelitian ini bertujuan untuk menganalisis eksternalitas TPST Piyungan baik eksternalitas positif maupun negatif. Obyek penelitian ini adalah masyarakat yang tinggal di sekitar TPST Piyungan pada jarak $\leq 1 \mathrm{~km}$ dari TPST Piyungan. Pengumpulan data primer menggunakan kuesioner, observasi dan wawancara, dengan 120 orang responden menggunakan metode sensus. Alat analisis yang digunakan dalam penelitian ini adalah statistik deskriptif, analisis pendapatan, nilai tambah, cost of illness dan replacement cost. Hasil penelitian menunjukkan bahwa keberadaan TPST Piyungan memberikan pengaruh terhadap aspek ekonomi, sosial dan lingkungan masyarakat sekitarnya. Estimasi nilai eksternalitas positif yang diperoleh sebesar Rp109.847.940,00/tahun dan estimasi nilai eksternalitas negatif bagi masyarakat adalah sebesar Rp71.343.000,00 /tahun. Pemanfaatan sampah anorganik dari TPST Piyungan menghasilkan nilai tambah sebesar Rp632,00/kg pada pemulung dan Rp392,00/kg pada pengepul.

Kata Kunci: eksternalitas, cost of illness, replacement cost, nilai tambah, Tempat Pengolahan Sampah Terpadu (TPST)

Klasifikasi JEL: H23, I15, F64 


\section{PENDAHULUAN}

Permasalahan sampah merupakan salah satu tantangan yang harus dihadapi oleh setiap kabupaten/kota di Indonesia. Berdasarkan pada data dari Kementerian Lingkungan Hidup (2012) dalam Kajian Timbulan dan Komposisi Sampah Perkotaan (2015), volume sampah di Indonesia pada tahun 2010 mencapai 200.000 ton/hari, dan mengalami trend naik secara signifikan yakni pada tahun 2012 volume sampah di Indonesia menjadi 490.000 ton/hari atau 178.850.000-ton dalam satu tahun.

Peningkatan jumlah penduduk beriringan dengan peningkatan konsumsi dan aktivitas ekonomi yang dilakukannya, hal ini akan berakibat pada peningkatan jumlah sampah yang dihasilkan. Di kota metropolitan dengan jumlah penduduk lebih dari 1 juta jiwa, mampu menghasilkan sampah 1.300 ton/hari dan di kota besar dengan jumlah penduduk antara 500.000-1.000.000 orang rata-rata menghasilkan sampah 480 ton/hari (Kajian Timbulan dan Komposisi Sampah Perkotaan BLH DIY, 2015).

Daerah Istimewa Yogyakarta termasuk salah satu kota besar di Indonesia dengan kepadatan penduduk yang cukup tinggi. Tingginya jumlah penduduk inilah yang menyebabkan terjadinya peningkatan jumlah timbulan sampah di Daerah Istimewa Yogyakarta. Berdasarkan pada hasil survei timbulan sampah yang dilakukan oleh BLH Daerah Istimewa Yogyakarta Tahun 2015, ratarata timbulan sampah dari perorangan di Daerah Istimewa Yogyakarta adalah sebanyak $0,44 \mathrm{~kg} /$ orang/hari.

Kepadatan penduduk Daerah Istimewa Yogyakarta terus meningkat, sehingga jumlah sampah yang dihasilkan juga akan semakin menigkat. Pada tahun 2011, dengan jumlah rumah tangga sebanyak 920.689 di Daerah Istimewa Yogyakarta mampu menghasilkan timbulan sampah sebesar $10.327 \mathrm{~m}^{3} /$ hari. Kemudian pada tahun 2012, dengan jumlah rumah tangga sebanyak 998.328, menghasilkan timbulan sampah sebesar $11.538 \mathrm{~m}^{3} /$ hari. Hal ini menunjukkan bahwa dengan semakin bertambahnya jumlah penduduk, produksi sampah yang dihasilkan juga semakin meningkat. Permasalahan sampah ini harus segera ditangani, agar tidak menimbulkan masalah yang lainnya (Data SLHD DIY, 2011; Data SLHD DIY, 2012). Berdasarkan pada profil Badan Lingkungan Hidup (BLH) Kota Yogyakarta Tahun 2013 menyebutkan bahwa sampah yang terangkut ke tempat pembuangan akhir sampah terbanyak adalah dari Kota Yogyakarta yakni sebanyak 34,89\%, Sleman sebesar 13,17\%, Kulon Progo 7,20\%, dan Bantul sebesar 1,91\% (Mulasari dkk., 2016).

Salah satu upaya yang dilakukan oleh pemerintah Daerah Istimewa Yogyakarta dalam menanganani masalah sampah tersebut adalah dengan mendirikan Tempat Pengolahan Sampah Terpadu (TPST) Piyungan. Menurut Hifdziyah (2011) Tempat Pembuangan Akhir Sampah (TPAS) merupakan salah satu barang publik yang disediakan oleh pemerintah, begitu pula dengan TPST Piyungan yang termasuk ke dalam jenis barang publik. Pengelolaan sampah juga merupakan suatu barang publik (Coad, 2000 dalam Jati, 2013). Salah satu karakteristik dari barang publik adalah barang yang manfaatnya dirasakan bersama dan dikonsumsikan bersama tetapi dapat terjadi kepadatan serta dapat dijual melalui pasar atau langsung oleh pemerintah (Mangkoesoebroto, 2000 dalam Hifdziyah, 2011).

Sampah yang diangkut ke TPST Piyungan berasal dari Kabupaten Bantul, Kabupaten Sleman dan Kota Yogyakarta. Sampah yang diangkut TPST Piyungan terus mengalami peningkatan setiap tahunnya. Pada tahun 2015 volume sampah yang masuk ke TPST Piyungan mencapai 158.599 ribu kg dan setiap harinya TPST Piyungan menampung 400-500-ton sampah. Pengelolaan TPST Piyungan dilakukan oleh Pemerintah Daerah Istimewa.

Keberadaan TPST Piyungan sebagai salah satu barang publik dapat menimbulkan eksternalitas baik positif maupun negatif. 
Eksternalitas juga merupakan salah satu penyebab terjadinya kegagalan pasar (Hifdziyah, 2011). Lokasi TPST Piyungan yang berdekatan dengan pemukiman warga. Masyarakat yang tingal di sekitar TPST Piyungan menerima berbagai eksternalitas akibat keberadaan TPST Piyungan tersebut. Eksternalitas merupakan sebuah keterkaitan antara suatu kegiatan dengan kegiatan lain yang tidak melalui mekanisme pasar dimana dari kegiatan tersebut menimbulkan manfaat dan biaya bagi pihk diluar pelaksana kegiatan tersebut. Eksternalitas lingkungan dapat diartikan sebagai manfaat dan biaya yang ditunjukkan oleh perubahan fisik hayati. Misalnya polusi air yang disebabkan limbah sebuah perusahaan, polusi ini termasuk dalam eksternalitas lingkungan, dimana polusi tersebut telah merubah baik secara fisik maupun hayati sungai yang berada di sekitar perusahaan tersebut (Juliansah, 2010).

Dalam menangani keberadaan tempat pembuangan akhir sampah sebagai sumber pencemaran lingkungan dan dapat menimbulkan gangguan kesehatan bagi masyarakat, terutama masyarakat yang tinggal di sekitar TPST Piyungan, maka diperlukan sebuah pengelolaan yang tepat agar eksternalitas negatif dari keberadaan TPST Piyungan dapat diminimalkan. Berdasarkan pada adanya eksternalitas baik positif maupun negatif yang dirasakan oleh masyarakat, maka perlu untuk dilakukan penelitian mengenai eksternalitas dari keberadaan TPST Piyungan terhadap masyarakat di sekitarnya, untuk selanjutnya dapat dilakukan upaya mengembangkan eksternalitas positif dan mengatasi eksternalitas negatif yang dirasakan masyarakat sekitar TPST Piyungan serta bagaimana rantai nilai dan nilai tambah sampah anorganik yang diterima pemulung dan pengepul dari TPST Piyungan. Rantai nilai merupakan suatu cara untuk memandang suatu bisnis sebagai sebuah rantai aktivitas yang mengubah input menjadi output yang bernilai bagi pelanggan. Rantai nilai mencakup margin laba karena markup diatas biaya perusahaan untuk menyediakan aktivitas bernilai tambah umumnya merupakan bagian dari harga yang dibayarkan oleh pembeli (Apriliyanti, 2014).

\section{METODE PENELITIAN}

Penelitian ini dilaksanakan pada bulan Juni-Desember 2016 di Tempat Pengolahan Sampah Terpadu (TPST) Piyungan, Kabupaten Bantul, Daerah Istimewa Yogyakarta meliputi observasi awal hingga pengumpulan data dengan kuesioner dan wawancara. Subjek penelitian ini adalah masyarakat yang tinggal di sekitar TPST Piyungan pada radius $\leq 1 \mathrm{~km}$ dari lokasi TPST Piyungan.

Jenis data yang digunakan dalam penelitian ini adalah data primer dan data sekunder. Data primer diperoleh dengan cara survei yakni melalui kuesioner, observasi dan wawancara. Data sekunder diperoleh dari dokumen dan laporan dari kantor pengelola TPST Piyungan serta dari pihak-pihak terkait dengan penelitian ini. Untuk menguji alat ukur yang digunakan serta data yang diperoleh dilakukan uji validitas dan uji reliabilitas.

Teknik pengambilan sampel dalam penelitian ini menggunakan metode sensus, dimana seluruh populasi digunakan sebagai sumber data (Adinata, 2011). Jumlah KK di sekitar TPST Piyungan pada radius $\leq 1 \mathrm{~km}$ tahun 2016 adalah 120 KK. Responden penelitian ini adalah 120 orang yang merupakan perwakilan dari setiap KK.

\section{Uji Validitas dan Reliabilitas}

Uji validitas yang digunakan untuk menunjukkan sejauh mana daftar pertanyaan dapat mengukur dampak eksternalitas dari TPST Piyungan menggunakan rumus product moment coefficient of correlation sebagai berikut:

$$
r=\frac{\mathrm{N}\left(\sum \mathrm{XY}\right)-\left(\sum \mathrm{X} \sum \mathrm{Y}\right)}{\sqrt{\left[\mathrm{N} \sum \mathrm{X}^{2}-\left(\sum \mathrm{X}\right)^{2}\right]\left[\mathrm{N} \sum \mathrm{Y}^{2}-\left(\sum \mathrm{Y}\right)^{2}\right.}}
$$


Keterangan:

$\mathrm{X}=$ nomor item

$\mathrm{Y}=$ skor total

$\mathrm{N}=$ jumlah responden

Uji reliabilitas dilakukan untuk mengetahui ketepatan dari alat ukur yang digunakan (Kuncoro, 2013). Perhitungan reliabilitas harus dilakukan hanya pada item-item yang sudah memiliki validitas. Instrumen dikatan reliabel jika nilai Cronbach Alpha > 0,6 (Sari, 2015).

\section{Analisis Data}

Analisis data yang digunakan dalam penelitian ini adalah analisis statistik deskriptif, analisis nilai tambah, analisis pendapatan, cost of illness dan replacement cost.

1. Analisis Eksternalitas TPST Piyungan.

Analisis statistik deskriptif digunakan untuk menganalisis bentuk-bentuk eksternalitas dari TPST Piyungan dengan cara mendeskripsikan data yang terkumpul sesuai dengan fakta di lapangan.

2. Estimasi Nilai Eksternalitas Positif dan Negatif Dari TPST Piyungan.

Estimasi nilai eksternalitas positif diperoleh dengan menggunakan analisis pendapatan dengan menjumlahkan pendapatan bersumber langsung dari TPST Piyungan yang diterima masyarakat sekitar yakni masyarakat yang berkerja sebagai pemulung, buruh pengepul, ternak, masyarakat setempat yang bekerja sebagai karyawan TPST Piyungan dan pengepul. Adapun rumus pendapatan (Senja, 2010):

$$
\pi=T R-T C
$$

Keterangan:

$\mathrm{TR}=$ Total Penerimaan

$\mathrm{TC}=$ Total Biaya

$\pi=$ Pendapatan Usaha Ternak

Menurut Bujagunasti (2009), estimasi total eksternalitas positif dihitung dengan rumus:

Estimasi total $=\mathrm{I}_{1}+\mathrm{I}_{2}+\ldots \ldots+\mathrm{I}_{n}$

Keterangan:

$\mathrm{I}_{\mathrm{n}}=$ rata-rata pendapatan masyarakat yang

bersumber dari TPST Piyungan
Estimasi eksternalitas negatif diperoleh dengan menggunakan metode cost of illness yaitu biaya pengobatan yang dikeluarkan akibat adanya pencemaran dan replacement cost atau biaya pengganti, dalam penelitian ini biaya pengganti dihitung dari besarnya biaya untuk memperoleh air bersih akibat adanya pencemaran air pada sumur masyarakat.

a. Replacement Cost (Biaya Pengganti).

Biaya pengganti digunakan untuk mengestimasi eksternalitas negatif akibat tercemarnya air sumur warga, sehingga masyarakat harus menggunakan sumber air lain. Biaya pengganti konsumsi air bersih adalah biaya yang dikeluarkan untuk membeli air dengan tanki, galon, PAM dan sumber air bersih lainnya. Penggunaan air bersih dihitung berdasarkan rata-rata konsumsi responden setiap bulannya. Menurut (Bujagunasti, 2009) biaya pengganti untuk memperoleh air dihitung dengan cara sebagai berikut:

$$
\mathrm{TP}_{\mathrm{air}}=\sum \mathrm{BA}
$$

Keterangan:

$\mathrm{TP}_{\text {air }}=$ Total biaya pembelian air bersih/tahun (Rp)

$\mathrm{BA}=$ Biaya pembelian air bersih/rumah

tangga/tahun (Rp)

\section{b. Cost of illness (Biaya Berobat).}

Eksternalitas negatif diestimasi dengan menggunkan metode cost of illness atau biaya pengobatan yang ditanggung oleh masyarakat untuk mengobati penyakit yang mereka derita akibat nyamuk, lalat, pencemaran udara dan air serta sumber-sumber penyakit lain yang berasal dari TPST Piyungan. Total biaya yang dihitung hanyalah biaya langsung. Biaya langsung adalah biaya yang dikeluarkan untuk mengobati penyakit yang diderita antara lain meliputi biaya perawatan rumah sakit, perawatan saat penyembuhan dan obat-obatan. Data yang digunakan untuk melakukan estimasi ini menggunakan data primer dari responden dengan format sebagi berikut (Pahlefi, 2014):

$$
\mathrm{BP}=\mathrm{BP}_{\mathrm{RT}} \times \text { Intensitas }
$$

$$
\mathrm{TBP}=\sum \mathrm{BP}
$$


Keterangan:

$\mathrm{BP}$ = Biaya pengobatan $/$ rumah

tangga/tahun (Rp)

$\mathrm{BP}_{\mathrm{RT}}=$ Biaya pengobatan $/$ rumah tangga (Rp)

Intensitas = Intensitas penyakit/tahun

TBP $=$ Total biaya

pengobatan/tahun (Rp)

Total estimasi nilai eksternalitas negatif diperoleh dengan menjumlahkan total biaya pengobatan dan total biaya pembelian air bersih (Pahlefi, 2014), dengan rumus sebagai berikut:

Total nilai eksternalitas negatif $=\mathrm{TP}_{\mathrm{air}}+\mathrm{TBP}$ Keterangan:

$\mathrm{TP}_{\text {air }}=$ Total biaya pembelian air bersih/tahun (Rp)

$\mathrm{TBP}=$ Total biaya pengobatan/tahun $(\mathrm{Rp})$

c. Analisis Nilai Tambah

Analisis nilai tambah digunakan untuk mengetahui nilai tambah sampah anorganik dari TPST Piyungan dalam kegiatan daur ulang sampah yang diterima oleh pemulung dan pengepul. Nilai tambah suatu produk adalah perbedaan nilai serta pertambahan nilai suatu produk setelah mengalami proses pengolahan dalam suatu proses produksi, dalam proses pengolahan nilai tambah dapat diartikan sebagai selisih antara nilai produk dengan nilai biaya bahan baku dan input lainnya tidak termasuk tenaga kerja (Kairupan dkk., 2016). Dalam analisis nilai tambah sampah anorganik dari TPST Piyungan, dapat digunakan rumus nilai tambah sebagai berikut:

$\mathrm{NTp}=\mathrm{Na}-(\mathrm{Bb}+\mathrm{Bp}+\mathrm{Bbp})=\mathrm{Na}-\mathrm{Ba}$

Keterangan :

NTp = Nilai tambah $(\mathrm{Rp})$

$\mathrm{Na}=$ Nilai akhir $(\mathrm{Rp})$

$\mathrm{Ba}=$ Biaya antara $(\mathrm{Rp})$

$\mathrm{Bb}$ = Biaya bahan baku (Rp)

$\mathrm{Bp}=$ Biaya penyusutan alat $(\mathrm{Rp})$

Bbp = Biaya bahan penolong $(\mathrm{Rp})$

(Kairupan dkk., 2016)

\section{HASIL DAN PEMBAHASAN}

\section{Uji Kualitas Instrumen dan Data}

Uji validitas ini dilakukan dengan menggunakan rumus product moment coefficient of correlation dan dikatakan valid jika dari hasil uji diperoleh nilai korelasi antara skor setiap item dengan skor total signifikan pada tingkat $5 \%$ dan setaip item memiliki korelasi ( $\mathrm{r}$ ) dengan dengan skor total masing-masing variabel $\geq$ 0,25 (Basuki, 2015). Hasil uji validitas dari masing-masing dampak yaitu ekonomi, sosial dan lingkungan menunjukkan kesimpulan valid.

Uji reliabilitas dilakukan untuk mengetahui ketepatan dari alat ukur yang digunakan dalam penelitian. Perhitungan reliabilitas harus dilakukan hanya pada itemitem yang sudah memiliki validitas. Suatu variabel dikatakan reliabel jika memiliki nilai Cronbach's Alpha > 0,6 (Sari,2015). Dari hasil uji reliabilitas dapat dilihat bahwa nilai Cronbach's Alpha dari masing-masing variabel lebih besar dari 0,6, maka dapat disimpulkan bahwa keseluruhan instrumen yang digunakan dalam variabel ini adalah reliabel.

\section{Estimasi Nilai Eksternalitas Positif dan Negatif TPST Piyungan.}

a. Estimasi Nilai Eksternalitas Positif.

Keberadaan TPST Piyungan menimbulkan eksternalitas positif bagi masyarakat yang tinggal di sekitar TPST Piyungan, eksternalitas positif yang diterima masyarakat antara lain terbukanya lapangan kerja baru, sehingga banyak masyarakat yang mendapatkan penghasilan bersumber dari keberadaan TPST Piyungan tersebut. Pekerjaan tersebut antara lain menjadi pemulung, pengepul, buruh pengepul, menjadi karyawan TPST Piyungan dan peternak. Selain itu keberadaan TPST Piyungan juga meningkatkan tumbuhnya lapangan usaha baru, seperti adanya jasa pengangkut sampah dan warung makan.

Dalam estimasi nilai eksternalitas positif ini, yang diperhitungkan hanyalah manfaat langsung yang diterima masyarakat dari TPST Piyungan yakni berupa pendapatan yang 
diperoleh dari bekerja sebagai pemulung, pengepul, buruh pengepul, masyarakat

setempat yang bekerja sebagai karyawan TPST dan pendapatan dari ternak.

Tabel 1. Pendapatan Bersumber Langsung Dari TPST Piyungan

\begin{tabular}{clcc}
\hline No. & Sumber Pendapatan & Pendapatan/Bulan (Rp/Bulan) & Pendapatan/Tahun (Rp/Tahun) \\
\hline 1. & Pemulung & 1.173 .636 & 14.083 .632 \\
\hline 2. & Pengepul & 3.515 .385 & 42.184 .620 \\
\hline 3. & Buruh Pengepul & 993.200 & 11.918 .400 \\
\hline 4. & Ternak & 1.817 .229 & 21.807 .253 \\
\hline 5. & Karyawan TPST & 1.654 .545 & 19.854 .540 \\
\hline & Total (Rp) & $\mathbf{9 . 1 5 3 . 9 9 5}$ & $\mathbf{1 0 9 . 8 4 7 . 9 4 0}$
\end{tabular}

Sumber: Data Primer Diolah, 2016

Dari tabel 1 diatas eksternalitas positif yang dirasakan masyarakat sekitar TPST Piyungan sebesar Rp109.847.940,00 per tahun. Nilai ini diperoleh dari penjumlahan pendapatan rata-rata total masyarakat yang bersumber dari TPST Piyungan selama satu tahun.

Bekerja sebagai pengepul memberikan pendapatan yang besar, dibandingkan dengan pendapatan dari sumber yang lainnya. Ternak juga memberikan manfaat bagi pendapatan masyarakat, pemeliharaan ternak di TPST Piyungan sangat mudah sebab tidak perlu mencarikan pakan bagi ternak tersebut. Ternak yang dimiliki masyarakat di TPST Piyungan, dalam jangka waktu 1-1,5 tahun rata-rata bertambah 1 ekor. Ternak ini juga dijadikan masyarakat sebagai tabungan yang terus bertambah nilai asetnya dan bisa dijual sewaktu ada kebutuhan yang memerlukan dana besar.

Tingkat kesejahteraan masyarakat disekitar TPST Piyungan mengalami peningkatan semenjak dibangunnya TPST Piyungan. Sebelum adanya TPST Piyungan,

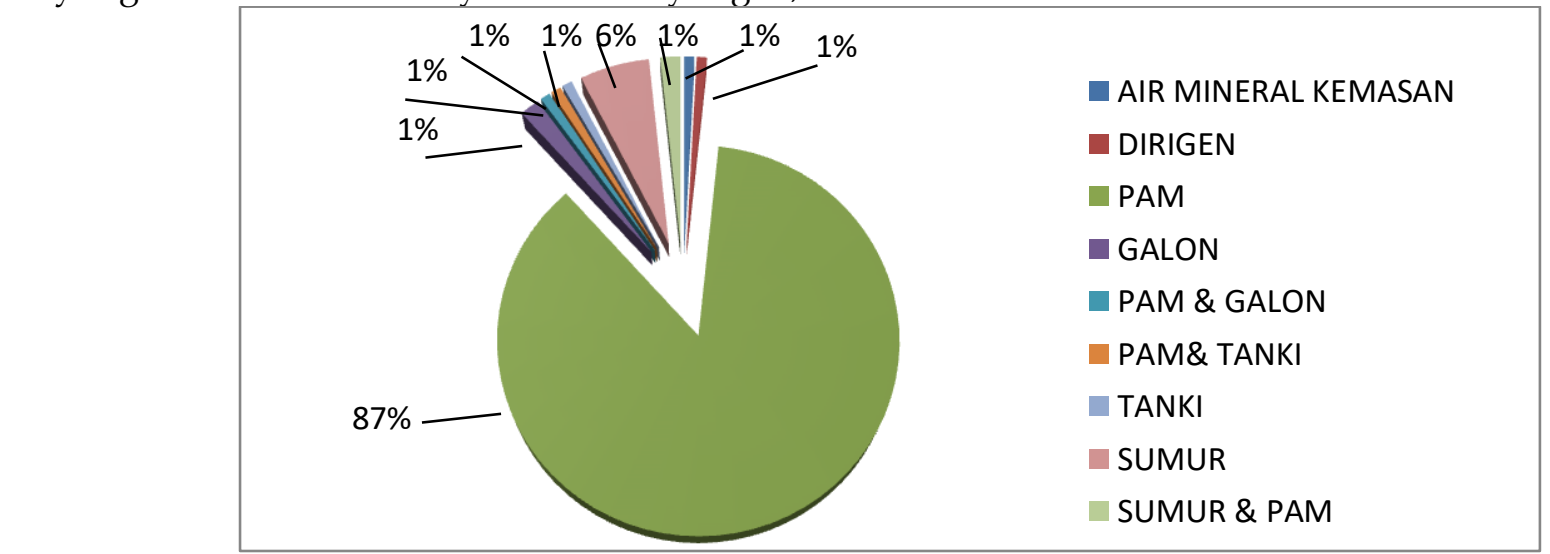

Sumber: Data Primer Diolah, 2016

Gambar 1. Sumber Air Bersih Masyarakat Sekitar TPST Piyungan mayoritas masyarakat bekerja sebagai buruh tani dan petani. Pendapatan yang diperoleh juga sangat minim, namun semenjak adanya TPST Piyungan kehidupan masyarakat menjadi lebih baik dan tidak ada warga yang menganggur.

\section{Estimasi Nilai Eksternalitas Negatif TPST Piyungan.}

Eksternalitas negatif yang dialami oleh masyarakat akibat keberadaan TPST Piyungan diestimasi dengan menggunakan dua metode yaitu biaya pengganti (replacement cost) dan biaya pengobatan (cost of illness).

1) Biaya Pengganti (Replcement Cost).

Metode yang digunakan untuk mengestimasi nilai eskternalitas negatif dari adanya pencemaran air adalah dengan metode replacement cost dari adanya biaya pengganti untuk sumber air bersih. Adapun sumber air bersih yang digunakan masyarakat dapat dilihat pada gambar berikut: 
Sebagian besar masyarakat yakni sebanyak 104 keluarga (87\%) memenuhi kebutuhan air bersih hanya dari PAM, dikarenakan sebagian besar air sumur yang dimiliki masyarakat sudah tidak digunakan lagi sejak adanya TPST Piyungan. Meskipun masih terdapat 7 keluarga (6\%) yang menggunakan air sumur, mereka tetap menggunakan air sumur dengan alasan air sumur mereka tidak tercemar limbah dari TPST sebab sumur mereka berada jauh dari aliran limbah TPST dan berada pada daerah yang lebih tinggi dari TPST.

Tabel 3. Biaya Pengganti Konsumsi Air Bersih

\begin{tabular}{lccc}
\hline Jenis Sumber Air & $\begin{array}{c}\text { Jumlah } \\
\text { Responden } \\
(\text { KK) }\end{array}$ & $\begin{array}{c}\text { Total Pengeluran } \\
\text { (Rp/Bulan) }\end{array}$ & $\begin{array}{c}\text { Total Biaya } \\
\text { Pengganti } \\
\text { (Rp/Tahun) }\end{array}$ \\
\hline PAM & 107 & 4.328 .000 & 51.936 .000 \\
\hline Galon & 3 & 193.500 & 2.322 .000 \\
\hline Tanki & 2 & 180.000 & 2.160 .000 \\
\hline Air Mineral Kemasan & 1 & 165.000 & 1.980 .000 \\
\hline \multicolumn{4}{c}{ Total Biaya Konsumsi Air Bersih Yang Dikeluarkan } \\
& & $\mathbf{5 8 . 3 9 8 . 0 0 0}$ \\
\hline
\end{tabular}

Estimasi nilai eksternalitas negatif dari biaya pengganti ini dihitung dari besarnya biaya yang dikeluarkan masyarakat untuk memenuhi kebutuhan air bersih. Dari 120 responden terdapat 8 keluarga yang tidak mengeluarkan biaya untuk memenuhi kebutuhan air bersih sebab mereka menggunakan air sumur dan air dengan dirigen yang bersumber dari saudaranya, sehingga tidak mengeluarkan biaya untuk memenuhi kebutuhan air bersih.
Sumber: Data Primer Diolah, 2016

Estimasi nilai eksternalitas negatif dari biaya pembelian air bersih yang dikeluarkan masyarakat sekitar TPST Piyungan adalah sebesar Rp58.398.000,00 per tahun. Angka ini diperoleh dengan menjumlahkan seluruh pengeluaran rata-rata masyarakat untuk memenuhi kebutuhan air bersih. Dari 112 responden terdapat 104 keluarga yang hanya mengeluarkan biaya untuk air PAM, terdapat 1 keluarga yang menggunakan PAM dan Galon, 1 keluarga yang menggunakan PAM dan tanki, 1 keluarga menggunakan PAM dan Sumur, 1 keluarga yang menggunakan tanki saja, 2 keluarga menggunakan galon saja dan 1 keluarga yang menggunakan air mineral dalam kemasan sebagai sumber air minum. Sehingga total terdapat 107 keluarga yang menggunakan PAM, 3 keluarga menggunakan galon, 2 keluarga menggunakan tanki, dan 1 keluarga menggunakan air mineral kemasan.

2) Biaya Pengobatan (Cost of Illness). 
gratis dari pihak TPST Piyungan yang bekerjasama dengan Rumah Sakit Rajawali Citra. Namun, pengobatan gratis ini hanya dilakukan dua kali dalam satu tahun. Terkadang masyarakat menderita sakit diluar waktu adanya pengobatan gratis tersebut, sehingga masyarakat tetap harus mengeluarkan biaya untuk pengobatan.

Adapun biaya yang dikeluarkan untuk menyelenggaran pengobatan gratis ini adalah sebagai berikut:

Tabel 4. Biaya Pengobatan Gratis Bagi Warga Masyarakat Sekitar TPST Piyungan Tahun 2015-2016

\begin{tabular}{cclc}
\hline No. & Tahun & \multicolumn{1}{c}{ Pengeluaran } & Biaya (Rp) \\
\hline 1 & 2015 & $\begin{array}{l}\text { Pemeriksaan dokter dan Obat/farmasi } \\
\text { penunjang medik }\end{array}$ & 17.250 .000 \\
\hline 2 & 2016 & $\begin{array}{l}\text { Pemeriksaan dokter dan Obat/farmasi } \\
\text { penunjang medic }\end{array}$ & 18.000 .000 \\
\hline & TOTAL & $\mathbf{3 5 . 2 5 0 . 0 0 0}$ \\
\hline
\end{tabular}

Sumber: Dokumen Kantor Pengelola TPST Piyungan, 2016

Dalam penelitian ini, biaya pengobatan setiap penyakit dihitung berdasarkan biaya pengobatan yang dikeluarkan dalam satu keluarga, tidak hanya biaya pengobatan untuk responden saja tetapi juga biaya pengobatan untuk anggota keluarga yang menjadi tanggungan responden. Berdasarkan wawancara yang dilakukan kepada responden penyakit yang sering mereka keluhkan adalah
ISPA dan sesak napas, serta ada beberapa responden yang bekerja sebagai pemulung sering mengalami sakit kulit atau dermatitis. Penyakit kulit yang diderita para pemulung disebabkan dari air limbah sampah yang masuk kedalam sepatu mereka, saat mereka bekerja. Berikut adalah biaya pengobatan total yang dikeluarkan oleh masyarakat dalam satu tahun terakhir:

Tabel 5. Biaya Pengobatan Responden Akibat Pencemaran

dari TPST Piyungan Tahun 2016

\begin{tabular}{lcc}
\hline Jenis Penyakit & $\begin{array}{c}\text { Jumlah } \\
\text { Penderita }\end{array}$ & $\begin{array}{c}\text { Total Biaya Pengobatan/ } \\
\text { tahun (Rp/tahun) }\end{array}$ \\
\hline ISPA & 35 & 12.455 .000 \\
\hline Penyakit Kulit & 4 & 490.000 \\
\hline Total & & $\mathbf{1 2 . 9 4 5 . 0 0 0}$ \\
\hline
\end{tabular}

Sumber: Data Primer Diolah, 2016

Pada tabel 5 biaya pengobatan akibat adanya pencemaran dari TPST Piyungan sebesar Rp12.945.000,00 per tahun. Nilai tersebut didapat dari biaya pengobatan masyarakat yang menderita penyakit akibat pencemaran dari TPST Piyungan selama satu tahun terakhir. Penyakit yang diderita masyarakat antara lain ISPA dan dermatitis atau penyakit kulit. Penyakit yang banyak diderita adalah ISPA yaitu sebanyak 35 responden. Bahkan terdapat responden yang harus menjalani rawat inap di rumah sakit karena menderita penyakit ISPA tersebut dan ada pula responden yang menjalani pengobatan rutin setiap 1 bulan sekali karena menderita ISPA. Selain ISPA, masyarakat juga sering mengalami penyakit kulit dan gatalgatal, penyakit ini banyak diderita oleh masyarakat yang bekerja sebagai pemulung yakni sebanyak 3 orang dan anak-anak yang menderita penyakit kulit terdapat 1 orang. Anak-anak yang menderita penyakit kulit ini, tempat tinggalnya sangat dekat dengan TPST Piyungan, serta sering bermain disekitar TPST Piyungan. 
Estimasi nilai total dari eksternalitas negatif TPST Piyungan didapat dengan menjumlahkan semua biaya yang dikeluarkan masyarakat, yakni biaya pengganti dan biaya pengobatan.

Tabel 6. Total Nilai Eksternalitas Negatif TPST Piyungan

\begin{tabular}{cc}
\hline Pengeluaran Biaya (Rp) & Total (Rp/tahun) \\
\hline Biaya Pengganti & 58.398 .000 \\
\hline Biaya Pengobatan & 12.945 .000 \\
\hline Total Nilai Kerugian Masyarakat & $\mathbf{7 1 . 3 4 3 . 0 0 0}$
\end{tabular}

Sumber: Data Primer Diolah, 2016

Hasil estimasi menunjukkan bahwa total nilai eksternalitas akibat keberadaan TPST Piyungan bagi masyarakat sebesar Rp71.343.000,00/ tahun. Biaya tersebut merupakan biaya pengobatan dan biaya pengganti yakni biaya pengobatan akibat penyakit yang diindikasikan kuat karena adanya pencemaran dari TPST Piyungan dan biaya pengganti yang dikeluarkan untuk memenuhi kebutuhan air bersih.

Berdasarkan hasil perhitungan estimasi nilai eksternalitas positif dan negatif, diperoleh hasil bahwa estimasi nilai eksternalitas positif TPST Piyungan lebih besar daripada estimasi nilai eksternalitas negatifnya. Estimasi nilai eksternalitas positif TPST Piyungan sebesar Rp109.847.940,00 per tahun, sementara estimasi nilai eksternalitas negatif TPST Piyungan sebesar Rp71.343.000,00 per tahun.

Tingkat kepedulian masyarakat terhadap kesehatan dan kebersihan masih rendah, serta sistem kekebalan tubuh manusia yang sudah mampu beradaptasi dengan lingkungan sekitar juga menjadi salah satu faktor penyebab minimnya kerugian yang dirasakan masyarakat. Hal ini dapat terlihat dari sedikitnya masyarakat yang menderita penyakit pernafasan dan kulit akibat pencemaran dari TPST Piyungan. Hal ini sesuai dengan penelitian yang dilakukan oleh Pahlefi (2014), dimana estimasi nilai eksternalitas positif dari keberadaan TPA Rawa Kucing lebih besar daripada nilai eksternalitas negatifnya, akan tetapi pengelolaan sampah yang baik harus tetap diupayakan untuk menjaga kelestarian lingkungan. Kelestarian lingkungan harus tetap dijaga untuk keberlangsungan hidup generasi mendatang.

Eksternalitas negatif yang dirasakan masyarakat tidak hanya dirasakan pada masa sekarang tetapi juga pada masa yang akan datang (Bujagunasti, 2009). Eksternalitas negatif yang dirasakan masyarakat saat ini dinilai masih kecil daripada eksternalitas positif. Kurangnya kepedulian masyarakat terhadap kesehatan dan kebersihan lingkungan serta besarnya manfaat yang diperoleh masyarakat berupa peningkatan pendapatan, membuat masyarakat menilai bahwa kerugian dari TPST Piyungan sangat kecil. Namun, perlu disadari bahwa eksternalitas positif yang diterima masyarakat saat ini dapat menjadi lebih kecil dibandingkan dengan eksternalitas negatif yang akan diterima masyarakat akibat keberadaan TPST Piyungan dimasa yang akan datang berupa pencemaran lingkungan.

\section{Rantai Nilai Dan Nilai Tambah Sampah Anorganik Dari TPST Piyungan.}

Proses pemanfaatan sampah anorganik dari TPST Piyungan untuk di daur ulang berimplikasi pada adanya nilai tambah dari sampah tersebut, sehingga harga jual sampah menjadi lebih tinggi daripada sampah tersebut dibiarkan menumpuk di TPST Piyungan. Dalam proses pemanfaatan sampah dari TPST Piyungan terdapat rantai nilai yang dapat memberikan nilai tambah bagi semua pihak yang terlibat dalam kegiatan aliran rantai nilai tersebut.

Rantai nilai produk merupakan aktivitas yang berawal dari bahan mentah sampai dengan penanganan purna jual. Rantai nilai 
mencakup aktivitas yang terjadi karena hubungan dengan pemasok dan hubungan dengan konsumen (Baihaqi dkk., 2014). Rantai pasok adalah suatu proses atau aktivitas dalam pendistribusian barang mulai dari bahan baku hingga produk jadi dan sampai pada konsumen akhir (Anwar, 2011 dalam Cakswidryandani, 2016). Berdasarkan hasil penelitian maka diperoleh pola rantai pasok dari pemanfaatan sampah anorganik untuk daur ulang, seperti pada gambar 2.

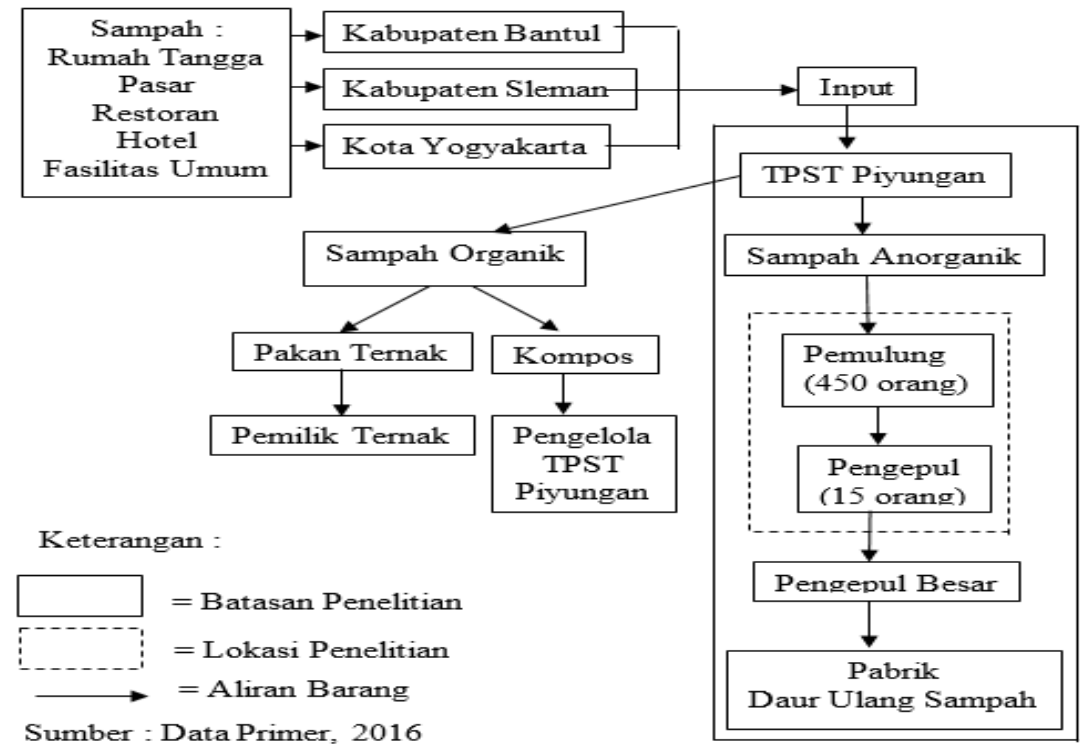

\section{Gambar 2. Pola Rantai Pasok Sampah TPST Piyungan}

Pemulung yang bekerja di TPST Piyungan kurang lebih berjumlah 450 orang dan pengepul yang menerima barang bekas dari pemulung berjumlah 15 orang. Alur rantai pasok sampah anorganik TPST Piyungan dimulai dari adanya sampah rumah tangga, restoran, hotel, pasar dan fasilitas umum yang berasal dari Kabupaten Bantul, Kabupaten Sleman dan Kota Yogyakarta yang masuk ke TPST Piyungan. Sampah yang masuk TPST Piyungan tersebut terdiri dari sampah organik dan anorganik.

Sampah organik dimanfaatkan sebagai pakan ternak dan pupuk kompos. Sampah organik yang digunakan sebagai pakan ternak memberikan manfaat bagi pemilik ternak, dimana pemilik ternak tidak kesulitan untuk mencarikan pakan bagi ternak mereka sebab ternak yang mereka miliki digembalakan di TPST Piyungan. Sampah organik yang diolah menjadi pupuk kompos oleh pengelola TPST Piyungan dimanfaatkan sendiri untuk pupuk tanaman yang ada di sekitar TPST Piyungan, kompos yang dihasilkan belum diperjualbelikan dikarenakan jumlah produksi yang masih sedikit dan belum adanya standar operasional (SOP) dari pihak pemerintah daerah.

Sampah anorganik dimanfaatkan oleh pemulung untuk dilakukan proses daur ulang sampah. Rantai pasok sampah anorganik dimulai dari adanya sampah anorganik yang berasal dari rumah tangga, pasar dan lain-lain yang masuk ke TPST Piyungan-pemulungpengepul-pengepul besar-pabrik daur ulang sampah.

Aliran pemanfaatan sampah anorganik dari TPST Piyungan ke pembeli akhir akan mengubah nilai dari sampah tersebut. Nilai sampah mengalami perubahan pada setiap terminal penjualan, dalam penelitian ini yaitu para pengepul sampah. Perubahan nilai sampah terjadi karena adanya pemrosesan pada sampah tersebut. 
Jenis sampah yang pada umumnya diperjualbelikan di daerah penelitian yaitu plastik, kertas, tulang, logam, botol air mineral, karung dan lain-lain. Komoditas utama sampah yang banyak diperjualbelikan dan dijual secara rutin setiap minggu yaitu plastik dan kertas. Plastik terdiri dari berbagai macam jenis seperti kantong plastik, plastik ember, plastik gelas air mineral, botol air mineral dan masih banyak lagi dengan rata-rata harga jual yang sama.
Kertas juga terdiri dari beberapa macam antara lain kardus, sak semen, buram, arsip dan duplek dengan rata-rata harga jual yang sama. Harga sampah plastik dan kertas dari pemulung rata-rata sama karena sampahsampah tersebut masih bercampur dan belum dipisah sesuai jenisnya (Wawancara dengan Bapak Sutris (pengepul), 20 November 2016).

Berikut ini adalah aliran rantai nilai dari sampah plastik dan kertas:

- Rantai Nilai Sampah Plastik

\begin{tabular}{|c|c|}
\hline $\begin{array}{c}\text { Pemulung } \\
\text { Harga Jual } \\
\text { Rp700,00/kg }\end{array}$ & $\begin{array}{c}\text { Pengepul Kecil } \\
\text { Harga Beli: Rp700,00/kg } \\
\text { Harga Jual: Rp1.200,00/kg }\end{array}$ \\
\end{tabular}

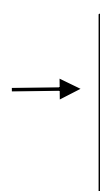

\section{Pengepul Besar}

Harga Beli: Rp1.200,00/kg Harga Jual: Rp4.000,00/kg

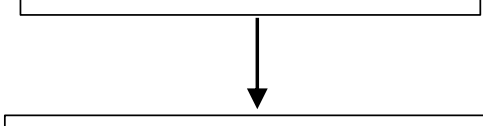

Pabrik Daur Ulang Sampah

Harga Beli: Rp4.000,00/kg

- Rantai Nilai Sampah Kertas

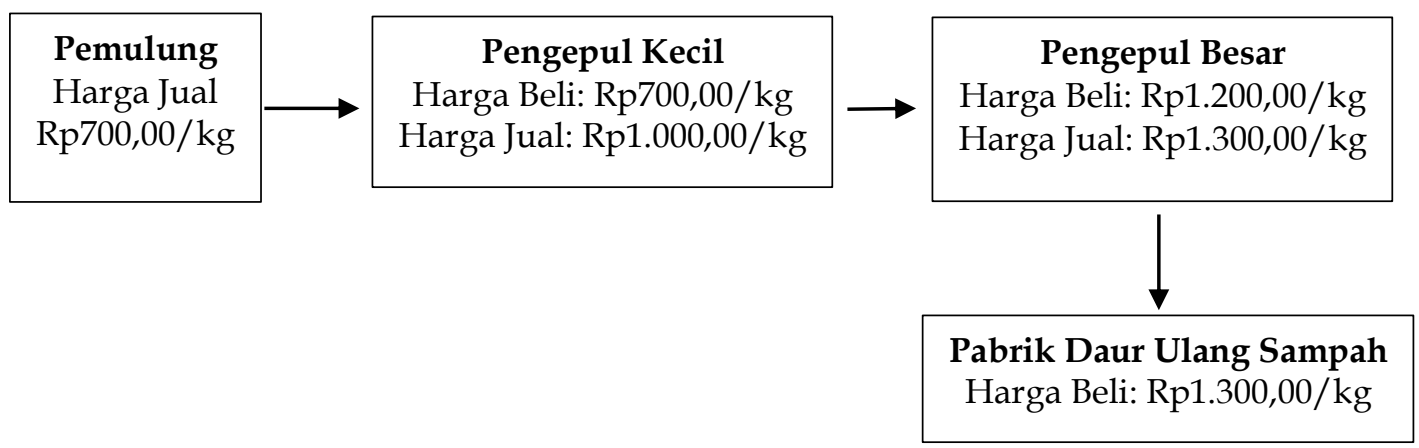

(Sumber: Data Primer, 2016)

\section{Gambar 3. Aliran Rantai Nilai/ Nilai Jual Sampah Anorganik Pada Kegiatan Daur Ulang Sampah}

Pada gambar 3 menunjukkan aliran rantai nilai dari dua komoditas utama sampah yang pada umumnya diperjualbelikan di kawasan sekitar TPST Piyungan. Aliran rantai nilai sampah tersebut dapat dijelaskan sebagai berikut:

1. Berdasarkan hasil penelitian diketahui bahwa harga jual sampah plastik dan sampah kertas rata-rata Rp700,00 per kg. Pemulung menjual sampah hasil memulung tersebut seminggu sekali. Hasil yang

diterima oleh pemulung ditentukan berdasarkan jumlah sampah yang mereka kumpulkan, dimana hal ini dipengaruhi oleh kekuatan fisik dari masing-masing pemulung. Tidak semua jenis sampah bisa dijual setiap seminggu sekali, untuk sampah jenis logam, kaleng dan kaca dijual setiap satu bulan sekali dan tidak menentu 
dikarenakan jumlahnya yang tidak terlalu banyak.

2. Pada pengepul, sampah mengalami beberapa pemrosesan, yakni sampah dipilah sesuai dengan jenisnya dan dibersihkan. Kemudian para pengepul tersebut menjual sampah kepada pengepul yang lebih besar dengan harga rata-rata Rp1.200,00 per kg untuk sampah plastik dan Rp1.000,00 untuk sampah kertas. Meskipun pengepul kecil mengambil selisih pembelian dan penjualan yang tidak terlalu besar yakni hanya Rp500,00 untuk sampah plastik dan Rp300,00 untuk sampah kertas, namun jumlah sampah yang dijual dalam satu kali penjualan cukup banyak yakni 1,53-ton untuk sampah plastik dan 2 hingga 4ton untuk sampah kertas. Penjualan dilakukan rata-rata 1 minggu sekali, dengan sistem pegepul besar datang kepada pengepul dan mengambil barang tersebut. Pengepul rata-rata juga memiliki tenaga kerja yang bertugas untuk memilah sampah dan melakukan pemrosesan terhadap sampah tersebut.

3. Pada tahap selanjutnya, pengepul besar melakukan pemrosesan lebih lanjut yakni memilah sampah sesuai dengan jenisnya dan melakukan penggilingan untuk sampah plastik, yang kemudian akan dijual ke pabrik-pabrik daur ulang sampah. Harga jual sampah dari pengepul besar ke pabrik yaitu Rp4.000,00 per kg untuk sampah plastik dan Rp1.300,00 per kg untuk sampah kertas. Pengepul besar melakukan penjualan sampah ke pabrik sebanyak 2 kali dalam seminggu dengan rata-rata penjualan 6 hingga 7-ton dalam sekali penjualan. Untuk sampah plastik pada umumnya dijual ke pabrik yang berada di Surabaya. Pada pengepul besar ini, barang rosok yang diperjualbelikan tidak hanya dari TPST Piyungan, namun dari berbagai daerah yang ada di Yogyakarta. Karyawan yang dimiliki pengepul besar bisa mencapai 200 orang (wawancara dengan karyawan
UD. Aneka Plastik (pengepul besar), 26 November 2016).

Analisis nilai tambah dari sampah dalam penelitian ini dilakukan pada tahap pemulung dan pengepul. Sampah yang menjadi komoditas utama adalah plastik dan kertas karena jumlahnya yang lebih banyak dibandingkan jenis sampah yang lain, serta penjualan sampah plastik dan kertas dilakukan secara rutin setiap minggu sementara jenis sampah lain seperti logam dijual satu bulan sekali dan tidak menentu. Harga jual dan harga beli sampah dari pemulung kepada pengepul dan dari pengepul kepada pengepul besar diasumsikan sama pada setiap pengepul yang ada di lokasi penelitian. Harga sampah di lokasi penelitian sangat dipengaruhi oleh harga yang ditentukan oleh pabrik daur ulang, sehingga rata-rata harga sampah plastik dan kertas sama disetiap pengepul kecil.

Pemulung yang mencari barang bekas di TPST Piyungan memerlukan beberapa peralatan saat bekerja, seperti sepatu boot, keranjang dan gancu. Untuk karung tempat hasil sampah yang sudah dikumpulkan, para pemulung tidak perlu mengeluarkan biaya sebab mereka hanya mengambil karung bekas dari TPST Piyungan. Serta hasil yang mereka peroleh dipengaruhi oleh kekuatan fisik mereka, sehingga mereka mengeluarkan biaya untuk konsumsi saat bekerja. Biaya-biaya yang harus ditanggung oleh pemulung dalam bekerja antara lain biaya penyusutan peralatan, dan biaya makan saat bekerja.

Sampah yang dikumpulkan pemulung dari TPST Piyungan bermacam-macam antara lain plastik, kertas, logam, kaleng, dan lain-lain. Namun, untuk barang yang rutin mereka jual setiap minggunya adalah plastik dan kertas, sebab dua jenis barang ini yang jumlahnya paling banyak dibandingkan jenis sampah yang lainnya. Logam dan kaleng dijual setiap satu bulan sekali dan tidak menentu, sebab jumlahnya sedikit. Dalam penelitian ini, nilai 
tambah sampah yang dihitung adalah nilai tambah dari sampah plastik dan kertas.

Tabel 7. Biaya Penggunaan Peralatan Pemulung Di TPST Piyungan

\begin{tabular}{lc}
\hline Nama Alat & Nilai Penyusutan (Rp/Minggu) \\
\hline Sepatu Boot & 9.792 \\
\hline Keranjang & 5.306 \\
\hline Gancu & 4.542 \\
\hline Total & 19.640
\end{tabular}

Sumber: Data Primer Diolah, 2016

Tabel 7 diatas memperlihatkan rata-rata total biaya penggunaan peralatan yang dikeluarkan pemulung di TPST Piyungan. Penjualan barang bekas dari pemulung ke pengepul kecil dilakukan setiap satu minggu sekali. Nilai penyusutan dari sepatu boot per minggu adalah Rp9.792,00, keranjang Rp5.306,00 dan gancu Rp4.542,00. Pemulung bekerja dengan memanfaatkan sampah anorganik yang ada di TPST Piyungan untuk memperoleh pendapatan. Modal utama bekerja sebagai pemulung adalah kekuatan fisik, untuk menjaga kekuatan fisik saat bekerja pemulung mengeluarkan biaya untuk makan. Dalam penelitian ini biaya konsumsi yang dihitung hanyalah biaya konsumsi pada saat bekerja saja.

Tabel 8. Penerimaan Pemulung Di TPST Piyungan

Uraian Jumlah (Rp/Minggu)

\begin{tabular}{llc}
\hline 1. & Penerimaan & \\
\hline & TR= 291,477 kg $\times 700$ & 204.034 \\
\hline 2. & Biaya-Biaya & \\
\hline & Biaya Penyusutan Alat & 19.640 \\
\hline Biaya Konsumsi Saat Kerja & 62.000 \\
\hline$\quad$ Total Biaya (TC) & 81.640 \\
\hline 3. & Pendapatan (TR-TC) & 122.394 \\
\hline
\end{tabular}

Sumber: Data Primer Diolah, 2016

Rata-rata biaya yang dikeluarkan pemulung dalam satu minggu sebesar Rp81.640,00. Jenis sampah yang paling banyak dikumpulkan pemulung adalah plastik dan kertas, dengan jumlah sampah yang dikumpulkan rata-rata 291,477 $\mathrm{kg}$ per minggu. Untuk rata-rata harga penjualan sampah plastik dan kertas dari pemulung kepada pengepul kecil adalah $\mathrm{Rp} 700,00$ per $\mathrm{kg}$, sehingga penerimaan pemulung per minggu rata-rata adalah Rp204.034,00. Setelah dikurangi dengan biaya-biaya, pendapatan bersih pemulung ratarata adalah Rp122.394,00 per minggu. Penerimaan pemulung dalam satu bulan bisa lebih besar dari nilai tersebut, sebab ada beberapa jenis sampah yang dijual setiap satu bulan sekali seperti logam, kaleng, tulang dan kaca. Harga jual logam tembaga rata-rata Rp40.000,00 per kg dan merupakan jenis sampah yang memiliki harga jual tertinggi.
Perhitungan analisis nilai tambah sampah yang dikumpulkan pemulung sekitar TPST Piyungan adalah sebagai berikut:

$\mathrm{NTp}=\mathrm{Na}-\mathrm{Ba}$

$$
=204.034-19.640
$$$$
=184.394
$$

Berdasarkan perhitungan tersebut nilai tambah yang didapat dari mengumpulkan sampah ini adalah Rp184.394,00 per minggu, dengan jumlah sampah rata-rata sebanyak 291,477 kg per minggu, maka nilai tambah dari sampah adalah sebesar Rp632,00/kg artinya untuk setiap satu kilogram sampah dari TPST Piyungan dapat memberikan penambahan nilai sebesar Rp632,00 pada pemulung. Nilai tambah yang diterima pemulung cukup besar sebab pemulung memanfaatkan sampah yang tidak bernilai menjadi barang yang bisa memberikan penghasilan dan biaya yang dikeluarkan pemulung tidak terlalu besar. Pemulung 
mengubah bahan baku yang tidak bernilai jual menjadi barang yang memiliki nilai jual.

Masyarakat sekitar TPST Piyungan yang berprofesi sebagai pengepul, sebagian besar termasuk kedalam kategori pengepul kecil yang menjual hasil rosok ke pengepul besar. Pengepul yaitu orang yang membeli barang bekas dari pemulung untuk kemudian dilakukan beberapa tahap pemrosesan dan dijual kepada pengepul barang bekas yang lebih besar. Dalam pemrosesan sampah dari pemulung, pengepul menggunakan tenaga kerja lokal setempat, dengan sistem pembayaran per hari.

\begin{tabular}{|c|c|}
\hline Nama Alat & Nilai Penyusutan (Rp/Minggu) \\
\hline Timbangan & 3.252 \\
\hline Alat Press & 8.459 \\
\hline Total & 11.711 \\
\hline
\end{tabular}

Sumber: Data Primer Diolah, 2016

Dalam usaha pemanfaatan sampah dari TPST Piyungan, pengepul menggunakan beberapa alat untuk memudahkan pekerjaannya.

Tabel 9 diatas memperlihatkan rata-rata total biaya penggunaan peralatan yang dikeluarkan pengepul di sekitar TPST Piyungan. Penjualan barang bekas dari pengepul ke pengepul besar dilakukan setiap satu minggu sekali. Nilai penyusutan dari timbangan per minggu adalah Rp3.252,00 dan alat press $\mathrm{Rp} 8.459,00$.

Bahan baku utama dalam usaha ini adalah sampah yang dikumpulkan oleh pemulung dari TPST Piyungan, untuk kemudian dilakukan beberapa pemrosesan oleh pengepul tersebut. Jumlah sampah yang paling banyak dikumpulkan oleh pemulung adalah plastik dan kertas. Sehingga dalam penelitian ini bahan baku utama bagi pengepul adalah plastik dan kertas, dengan asumsi tidak terdapat penyusutan berat bahan baku antara sebelum dan sesudah pemrosesan seperti yang terjadi pada saat musim kemarau. Berdasarkan keterangan yang diberikan oleh pengepul, sampah atau rosok yang dijual pemulung kepada pengepul pada saat musim kemarau tidak terjadi penyusutan berat setelah dilakukan pemrosesan.

Tabel 10. Rincian Pengeluaran Biaya Bahan Baku dan Bahan Penolong pada Pengepul dalam 1 Minggu

\begin{tabular}{|c|c|c|c|}
\hline Jenis Bahan Baku & Jumlah (Kg/Minggu) & Harga / Kg & $\begin{array}{l}\text { Jumlah Biaya } \\
\text { (Rp/Minggu) }\end{array}$ \\
\hline \multicolumn{4}{|l|}{ A. Bahan Utama } \\
\hline 1.Plastik & 2.788 & 700 & 1.951 .600 \\
\hline 2. Kertas & 2.051 & 700 & 1.435 .700 \\
\hline Jumlah & 4.839 & & 3.387 .300 \\
\hline B. Bahan Penolong & \multicolumn{2}{|c|}{ Jumlah (Buah/Minggu) } & $\begin{array}{c}\text { Biaya Rafia } \\
\text { (Rp/Minggu) }\end{array}$ \\
\hline 1. Rafia & & 4,46 & 50.538 \\
\hline \multicolumn{3}{|c|}{ Total } & 3.437 .838 \\
\hline
\end{tabular}

Sumber: Data Primer Diolah, 2016

Dari tabel 10 diatas, dapat dilihat bahwa jumlah biaya rata-rata bahan baku dan bahan sebesar Rp3.437.838,00 per minggu. Bahan penolong yang digunakan pengepul antara lain rafia, keranjang dan karung. Untuk karung dan penolong yang dikeluarkan pengepul adalah 
keranjang para pengepul tidak mengeluarkan biaya, sebab sampah yang dijual pemulung sudah menggunakan karung dan terkadang menggunakan keranjang. Tujuan dari sebuah usaha adalah untuk memperoleh keuntungan yang besar dan berkelanjutan. Keuntungan dari usaha ini adalah selisih dari penerimaan total dengan total biaya yang dikeluarkan.

Tabel 11. Penerimaan Dan Keuntungan Pengepul Di Sekitar TPST Piyungan

\begin{tabular}{|c|c|}
\hline Uraian & Jumlah (Rp/Minggu) \\
\hline \multicolumn{2}{|l|}{ 1. Penerimaan (TR) } \\
\hline Plastik $=2.788 \mathrm{~kg} \times 1.200$ & 3.345 .600 \\
\hline Kertas $=2.051 \mathrm{~kg} \times 1.000$ & 2.051 .000 \\
\hline Total Penerimaan (TR) & 5.396 .600 \\
\hline \multicolumn{2}{|l|}{ 2. Biaya-Biaya } \\
\hline Biaya Penyusutan Alat & 11.711 \\
\hline Biaya Bahan Baku & 3.437 .838 \\
\hline Biaya Tenaga Kerja & 1.050 .000 \\
\hline Biaya Bahan Penolong & 50.538 \\
\hline Total Biaya (TC) & 4.550 .087 \\
\hline 3. Pendapatan (TR-TC) & 846.513 \\
\hline
\end{tabular}

Sumber: Data Primer Diolah, 2016

Keseluruhan biaya yang dikeluarkan pengepul dalam satu minggu rata-rata sebesar Rp4.550.087,00. Dengan asumsi tidak terdapat penyusutan berat sampah maka dengan input sampah seberat $4.839 \mathrm{~kg}$ per minggu akan menghasilkan output sampah bersih dengan jumlah yang sama, hal ini seperti yang terjadi pada musim kemarau tidak terdapat penyusutan berat sampah (Sumber: wawancara denga Bapak Sokiran (pegepul), 26 November 2016). Harga penjualan rata-rata dari pengepul kepada pengepul besar adalah Rp1.200,00 per kg untuk sampah plastik dan Rp1.000,00 per kg untuk sampah kertas, maka penerimaan pengepul per minggu adalah Rp5.396.000,00. Setelah dikurangi dengan biaya-biaya keuntungan bersih pengepul kecil adalah Rp846.513,00 per minggu.

Perhitungan analisis nilai tambah usaha daur ulang sampah yang dilakukan pengepul sekitar TPST Piyungan adalah sebagai berikut:

$$
\begin{aligned}
\text { NTp } & =\mathrm{Na}-\mathrm{Ba} \\
& =5.396 .600-3.499 .632 \\
& =1.896 .968
\end{aligned}
$$

Berdasarkan perhitungan tersebut nilai tambah yang didapat dari usaha ini adalah Rp1.896.968,00 per minggu, dengan jumlah bahan baku sampah rata-rata sebanyak $4.839 \mathrm{~kg}$ per minggu, maka nilai tambah dari sampah adalah sebesar Rp392,00/kg artinya untuk setiap satu kilogram bahan baku sampah dari pemulung dapat memberikan penambahan nilai sebesar Rp392,00 pada pengepul. Usaha pemanfaatan sampah anorganik dari TPST Piyungan selain bisa mengurangi jumlah timbunan sampah di TPST juga mampu meningkatkan pendapatan masyarakat.

Nilai tambah yang diperoleh pengepul lebih rendah dibandingkan dengan nilai tambah yang diterima pemulung, karena pengepul menanggung biaya bahan baku yang cukup tinggi dan biaya bahan penolong. Tinggi rendahnya nilai tambah dipengaruhi oleh penggunaan biaya produksi, harga jual dan volume produksi (Baihaqi dkk., 2014).

Nilai tambah sampah anorganik dari TPST Piyungan merupakan salah satu eksternalitas positif dari TPST Piyungan, 
karena dapat meningkatkan pendapatan bagi pemulung dan pengepul. Nilai tambah yang diterima oleh pemulung lebih besar daripada nilai tambah yang diterima oleh pengepul hal ini disebabkan karena biaya yang dikeluarkan pengepul lebih besar dibandingkan dengan biaya yang dikeluarkan pemulung. Adanya nilai tambah dari sampah anorganik dalam usaha daur ulang sampah tersebut, mampu meningkatkan pendapatan masyarakat disekitar TPST Piyungan, khususnya pada pemulung dan pengepul yang pada akhirnya akan meningkatkan kesejahteraan masyarakat.

\section{SIMPULAN}

Penetapan TPST Piyungan menjadi solusi untuk permasalahan sampah di Daerah Istimewa Yogyakarta yang jumlahnya semakin meningkat, menimbulkan berbagai macam eksternalitas bagi masyarakat di sekitarnya. Berdasarkan penelitian tentang analisis eksternalitas TPST Piyungan diperoleh hasil sebagai berikut:

1. Eksternalitas positif dari keberadaan TPST Piyungan yaitu a). terbukanya lapangan kerja, b). terbuka peluang usaha bagi masyarakat, c). peningkatkan pendapatan, d). mengurangi jumlah pengangguran, e). meningkatkan kepedulian dan kerjasama antara masyarakat pendatang dengan masyarakat setempat, f). peningkatan pembangunan dan perbaikan sarana prasarana desa. Eksternalitas negatif dari TPST Piyungan adalah terjadinya penurunan kualitas lingkungan, yakni a). pencemaran udara dan air, serta b). penurunan kebersihan lingkungan. Eksternalitas negatif yang sangat dirasakan masyarakat adalah pencemaran udara berupa bau sampah.

2. Estimasi nilai eksternlitas positif yang diterima masyarakat sekitar TPST Piyungan berupa peningkatan pendapatan adalah sebesar Rp109.847.940,00 per tahun dan estimasi nilai eksternalitas negatif akibat keberadaan TPST Piyungan yang berupa pengeluaran biaya pengganti dan biaya pengobatan adalah sebesar Rp71.343.000,00 per tahun. Jadi, nilai eskternalitas positif dari TPST Piyungan lebih besar daripada nilai eksternalitas negatifnya, dengan estimasi nilai eksternalitas sebesar Rp38.504.940,00 per tahun.

3. Berdasarkan rantai nilai sampah dari TPST Piyungan, usaha daur ulang sampah dapat memberikan nilai tambah pada sampah tersebut dan usaha daur ulang sampah memiliki prospek yang menjanjikan untuk dapat meningkatkan pendapatan masyarakat dan angkatan kerja. Pola rantai nilai sampah anorganik TPST Piyungan yaitu pemulung-pengepul-pengepul besarpabrik daur ulang. Sampah yang dikumpulkan oleh pemulung dari TPST Piyungan mampu memberikan nilai tambah sebesar Rp632,00 per $\mathrm{kg}$ sampah untuk pemulung dan Rp392,00 per $\mathrm{kg}$ sampah untuk pengepul.

\section{DAFTAR PUSTAKA}

Adinata, A, 2011, Pengaruh Kompensasi Terhadap Kinerja Pegawai Dinas Pendapatan Daerah Kota Bogor, Skripsi. Bogor:Institut Pertanian Bogor.

Apriliyanti, Triana, 2014, Ananlisis Rantai Nilai (Value Chain) Tahu Kuning Di Sentra Industri Tahu Kecamatan Adiwerna, Kabupaten Tegal, Skripsi. Semarang: Fakultas Ekonomika Dan Bisnis Universitas Diponegoro.

Badan Lingkungan Hidup DIY, 2015, Kajian Timbulan dan Komposisi Sampah Perkotaan Studi di Kawasan Permukiman DIY 2015, Badan Lingkungan Hidup DIY, Yogyakarta.

Badan Lingkungan Hidup DIY, Statistik Lingkungan Hidup Daerah (SLHD) DIY Tahun 2011, http://blh.jogjaprov.go.id/pocontent/uploads/LSLHD_DIY_2011.pd f, diakses pada tanggal 28 Oktober 2016 pk 19.00 WIB 
Badan Lingkungan Hidup DIY, Statistik Lingkungan Hidup Daerah (SLHD) DIY Tahun 2012, http://blh.jogjaprov.go.id/pocontent/uploads/DATA-SLHD-DIY2012.pdf diakses pada tanggal 28 Oktober 2016 pk 19.00 WIB.

Badan Pusat Statistik, Daerah Istimewa Yogyakarta Dalam angka Tahun 2015, http://yogyakarta.bps.go.id/website/p df_publikasi/Daerah-IstimewaYogyakarta-Dalam-Angka-2015.pdf diakses pada tanggal 9 Oktober 2016 pk 21.12 WIB

Baihaqi, Akhad, dkk., 2014, "Analisis Rantai Nilai Dan Nilai Tambah Kakao Petani Di Kecamatan Poya Bakong Dan Geurodong Pase Kabupaten Aceh Utara", Jurnal Agrisep Vol (15) No.2.

Basuki, Agus Tri, 2015, Regresi Dalam Penelitian Ekonomi Dan Bisnis, Danisa Media, Yogyakarta.

Bujagunasti, Yudi, 2009, Estimassi Manfaat dan Kerugian Masyarakat Akibt Keberadaan Tempat Pembuangan Akhir Studi Kasus di TPA Bantar Gebang, Skripsi. Bogor: Fakultas Ekonomi dan Manajemen Institut Pertanian Bogor.

Hifdziyah, Lisanatul, 2011, Analisis Penurunan Kualitas Lingkungan Di Sekitar Tempat Pembuangan Akhir Sampah Galuga Kabupaten Bogor Jawa Barat, Skripsi. Bogor: Departemen Ekonomi Sumberdaya Dan Lingkungan.Fakultas Ekonomi dan Manajemen, Institut Pertanian Bogor.

Jati, T. K. (2013). Peran Pemerintah Boyolali Dalam Pengelolaan Sampah Lingkungan Permukiman Perkotaan (Studi Kasus: Perumahan Bumi Singkil Permai). Jurnal Wilayah dan Lingkungan, 1(1), 1-16.

Juliansah, Marthin Hadi, 2010, Analisis Keberadaan Tempat Pengelolaan Sampah Terpadu (TPST) Bantar Gebang Bekasi,
Tesis. Depok: Magister Perencanaan dan Kebijakan Publik Fakultas Ekonomi, Universitas Indonesia.

Kairupan, Grace A., dkk., 2016, “Analisis Nilai Tambah Akarwangi Pada Industri Minyak Atsiri Di Kabupaten Minahasa Utara", Jurnal Universitas Sam Ratulangi Manado,

http://ejournal.unsrat.ac.id/index.php/.

Diakses pada tanggal 28 November 2016 pk. 10.08 WIB.

Mulasari, A., dkk., 2016, "Analisis Situasi Permasalahan Sampah Kota Yogyakarta dan Kebijakan Penanggulangannya". Jurnal Kesehatan Masyarakat.

Pahlefi, Reza, 2014, Estimasi Nilai Eksternalitas dari Tempat Pemrosesan Akhir Sampah (Studi Kasus TPA Rawa Kucing Kota Tangerang), Skripsi. Bogor: Fakultas Ekonomi dan Manajemen Institut Pertanian Bogor.

Putri, Septi Hermaya, 2015, Analisis Ekonomi Dan Lingkungan Kegiatan Pertambangan Nikel (Studi Kasus: PT. ANTAM (Persero)Tbk.UBPN Sultra), Skripsi. Bogor: Fakultas Ekonomi Dan Manajemen Institut Pertanian Bogor.

Rendi, 2016, Pengaruh Debit Pada Proses Aerasi Dan Komposisi Tebal Media Filtrasi Terhadap Nilai BOD, COD, Dan TSS Pada Air Lindi (Studi KAsus Di TPA Piyungan, Bantul), Skripsi. Yogyakarta: Fakultas Sains Terapan, Institut Sains \& Teknologi AKPRIND Yogyakarta.

Sari, Andiny Khilsa Fatma, 2015, Eksternalitas Atas Keberadaan Desa Wisata Candran, Skripsi, Yogyakarta: Fakultas Ekonomi Universitas Muhammadiyah Yogyakarta.

Senja, Puput Yunita, 2010, Potensi Peternakan Sapi Pedaging Untuk Meningkatkan Kesejahteraan Masyarakat Di Tempat Pembuangan Akhir (TPA) Putri Cempo Mojosongo, Solo, Skripsi. Bogor: Institut Pertanian Bogor. 